
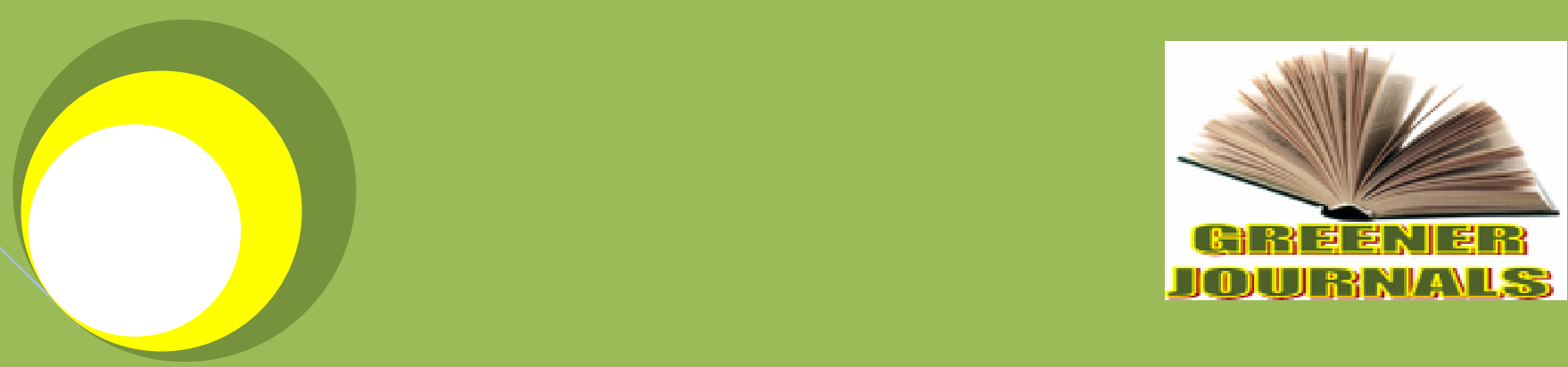

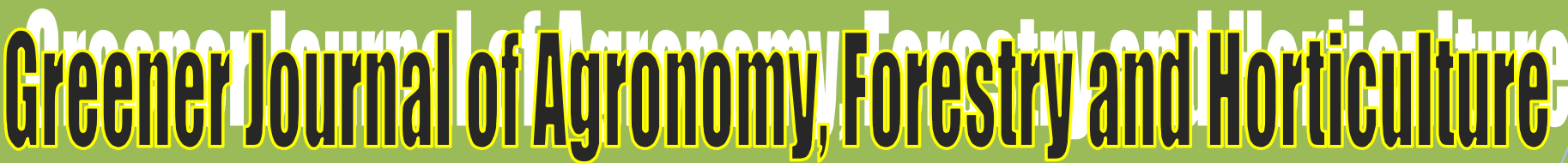

ISSN: 2354-2306

Submission Date: 01/08/014

Accepted: 27/08/014

Published: 09/09/014

Subject Area of Article: Agriculture

(DOI: http://dx.doi.org/10.15580/GJAFH.2014.4.080114315)

Impact of Phosphorous

Levels and Different

Tillage Systems on

Yield and Economics of

Mungbean (Vigna

radiata L.)

By

Muhammad Waseem Riaz Marral

Muhammad Shahid Ibni Zamir Shahid Iqbal 


\title{
Impact of Phosphorous Levels and Different Tillage Systems on Yield and Economics of Mungbean (Vigna radiata $\mathrm{L}$.
}

\section{Muhammad Waseem Riaz Marral ${ }^{1}$, Muhammad Shahid Ibni Zamir ${ }^{2}$ and Shahid Iqbal ${ }^{2}$}

${ }^{1}$ Department of Agronomy, Bahauddin Zakariya University, Multan, Pakistan.

${ }^{2}$ Department of Agronomy, University of Agriculture Faisalabad, Pakistan.

*Corresponding Author's Email: shahiduaf85@gmail.com

\begin{abstract}
Proper application of phosphorous $(P)$ dose and selection of an adequate tillage system could be effective in increasing the yield of crops. Therefore, a field experiment was conducted at Agronomic Research Area, University of Agriculture Faisalabad, Pakistan during summer, 2009, using different levels of phosphorous and tillage systems. There were three tillage systems (zero tillage, minimum tillage and conventional tillage) and three phosphorus levels (30, 60 and 90 kg P $\mathrm{ha}^{-1}$ ). Treatments were arranged in randomized complete block design (RCBD) with split plot arrangement. Results revealed that pods bearing branches per plant, seeds per plant and seed yield were significantly affected by various levels of applied phosphorous and tillage systems. Among different phosphorous levels, $90 \mathrm{~kg}^{\mathrm{P}} \mathrm{ha}^{-1} \mathrm{produced}$ maximum pods bearing branches per plant (4.52), seeds per plant (78.26) and seed yield (1064 kg ha ${ }^{-1}$ ). While, among different tillage systems, conventional tillage gave relatively better pods bearing branches per plant (4.8), seeds per plant $(81.81)$ and seed yield $\left(1142.3 \mathrm{~kg} \mathrm{ha}^{-1}\right)$ than others. However in case of interaction, the conventional tillage $+90 \mathrm{~kg} \mathrm{P}^{-1}$ performed better and gave the maximum pods bearing branches per plant (4.9), seeds per plant (94.71), straw yield (4090 $\left.\mathrm{kg} \mathrm{ha}^{-1}\right)$ and seed yield $\left(1243 \mathrm{~kg} \mathrm{ha}^{-1}\right)$ as compared to others. Conventional tillage $+90 \mathrm{~kg} \mathrm{P}^{-1}$ also gave higher gross income (1945 USD ha ${ }^{-1}$ ), net income (1568 USD ha ${ }^{-1}$ ) and benefit cost ratio (5.16). It was concluded from this study that conventional tillage $+90 \mathrm{~kg} \mathrm{P} \mathrm{ha}^{-1}$ could be successfully utilized on economic basis in order to get better seed yield in agro-climatic conditions of Faisalabad, Pakistan.
\end{abstract}

Keywords: Economics, phosphorous levels, tillage systems, seed yield.

\section{INTRODUCTION}

Grain legume is not only served as human diet but it is also used to improve the soil fertility through biological nitrogen fixation. Mungbean is one of the important grain legume crops and has high nutritive value and digestibility (Nazir et al., 2004). It contains rich amount of protein, vitamin A, iron, zinc and folate (Shanmugasundaram, 2004). Although, mungbean is an important crop in Pakistan, its total grain production (157.4 t) and average yield (514 kg $\mathrm{ha}^{-1}$ ) are much low (GOP, 2009).

Like other crops fertilizer is a key factor to improve the production of mungbean. Among different nutrients phosphorous is one of the important nutrients. Phosphorous favors the reproductive stage. In plant growth, phosphorous serve as energy storage and transfer. It is also an important structural component of a wide variety of bio-chemicals like nucleic acid, nucleotides, phosphor-proteins, phospholipids and sugar phosphate (Havlin et al., 2004). Therefore, phosphorous is much important for mungbean productivity (Khan et al., 2003). According to a study various levels of applied phosphorous significantly affected the growth and yield components of mungbean. However, highest level of phosphorous produced maximum yield as compared to other levels (Khan et al., 2003).

Tillage is done to pulverize the soil, prepare the seedbed for sowing, improve soil physical conditions and remove the weeds. Hence, tillage is an important factor which controls the crop yield (Armstrong et al., 2003; Rosner et al., 2008). In recent times, different tillage system like conventional tillage, zero tillage and minimum tillage are being utilized in crop production. In conventional tillage soil is disturbed more as compared to minimum tillage, while in zero tillage soil is left undisturbed. Only testing different tillage systems for a particular crop may determine role of tillage systems in increasing yield. 
Fertilizers are costly input and require large capital investment for crop production. On the other hand, tillage practices consume much energy as fuel which affects the economics of crop productivity. Therefore, it is dire need of time to adopt such tillage system and fertilizer level which are more economical and gave better yield. So far no/little work has been conducted yet which compare the phosphorous levels and tillage systems on mungbean productivity. Keeping in view the above facts, present study was conducted to evaluate the impact of phosphorous application levels and different tillage systems on yield and economics of mungbean.

\section{MATERIALS AND METHODS}

The field study was conducted at Agronomic Research Area, University of Agriculture, Faisalabad, Pakistan during summer, 2009. The experimental area lies between 30.35-31.47

$\mathrm{N}$ latitude and $72.08-73 \mathrm{E}$ longitude, at an elevation of $150 \mathrm{~m}$ from the sea level. The climate conditions of Faisalabad is very extreme with very little rainfall. Average annual precipitation lies on $300 \mathrm{~mm}$. The maximum temperature in summer rises up to $48{ }^{\circ} \mathrm{C}$ and minimum temperature in winter goes down to $4{ }^{\circ} \mathrm{C}$. Weather data collected during experiment is presented in Fig 1. Experimental soil was chemically analyzed before experimentation (Table 1). The experiment was laid out in randomized complete block design (RCBD) with split plot arrangement having three replications. The net plot size was $7 \mathrm{~m} \times 3 \mathrm{~m}$. The experiment comprised of three tillage systems (zero tillage, minimum tillage and conventional tillage) and three phosphorus levels $(30,60$ and $90 \mathrm{~kg} \mathrm{P} \mathrm{ha}$ $\left.{ }^{1}\right)$. Tillage systems were randomized in main plots while phosphorus levels were randomized in sub plots. The crop was sown on $29^{\text {th }}$ July, 2009 using a seed rate of $30 \mathrm{~kg} \mathrm{ha}^{-1}$ in $30 \mathrm{~cm}$ rows apart. The variety used was NM-2006. Phosphorus was side dressed at sowing. All other agronomic practices were kept normal and uniform.

Table 1. Chemical analysis of experimental soil

\begin{tabular}{lll}
\hline Determination & Units & Values \\
\hline Soil texture & -- & Sandy clay loam \\
$\mathrm{ECe}$ & $\mathrm{dS} \mathrm{m} \mathrm{m}^{-1}$ & 3.64 \\
$\mathrm{pH}$ & -- & 7.98 \\
Organic matter & $\%$ & 0.78 \\
Available phosphorus & $\mathrm{Ppm}$ & 6.1 \\
Available potassium & $\mathrm{Ppm}$ & 356 \\
Total N & $\%$ & 0.77 \\
Saturation & $\%$ & 38.96 \\
\hline
\end{tabular}

Temperature and Rainfall data during crop growing season

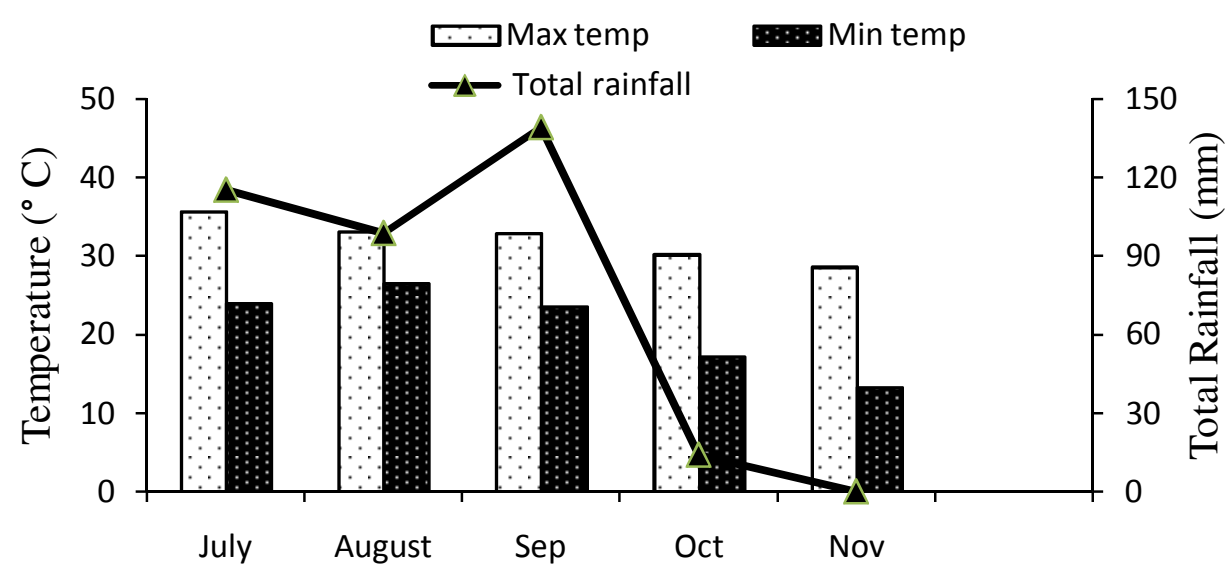

Months

Fig. 1 Weather conditions during the growing season of mungbean 
The data regarding seed yield and yield related parameters were recorded using standard methods. Pods bearing branches per plant was determined by selecting ten plants at random and their pods bearing branches were counted and then averaged. For seeds per plant, pods were separated from ten selected plants and seeds from pods were shelled, counted and then averaged. For straw yield, plants from each plot were harvested manually, sun dried, pods were separated from plants and straw weighed to determine the straw yield in $\mathrm{kg}$ per plot and then converted to $\mathrm{t}$ ha 1. For grain yield, pods were separated from each harvested plot, sun dried, shelled and their grains were weighed and finally converted into $\mathrm{tha}^{-1}$.

Data collected were analyzed statistically using Fisher's analysis of variance techniques (Steel et al., 1997). Differences among the treatments' means were compared by using least significant difference (LSD) at 5\% probability level. Economic analysis was also conducted for all the treatments in order to determine the gross income, net income and benefit cost ratio according to method described in CIMMYT manual (CIMMYT, 1988). The purpose of this analysis was to estimate the economic returns of each productivity level.

\section{RESULTS AND DISCUSSION}

Efforts were made in this study to check the effects of different levels of phosphorous and tillage systems on yield and yield related parameters and economics of mungbean production.

\section{Pods bearing branches per plant}

The maximum pods bearing branches per plant was obtained in conventional tillage which differed significantly from other tillage systems while lowest pods bearing branches per plant was obtained in zero tillage (Table 2). Highest pods bearing branches per plant in conventional tillage was due to constant supply of nutrients and moisture which increased the plant vigor. This improvement in plant vigor might have increased the pods bearing branches per plant. These results are in accordance with findings of Zamir (2006); Mukundam et al. (2009) who also observed highest pods bearing branches per plant with conventional tillage. In case of phosphorous levels, the maximum pods bearing branches per plant was observed where $90 \mathrm{~kg} \mathrm{P} \mathrm{ha}^{-1}$ was applied. The minimum pods bearing branches was recorded where $30 \mathrm{~kg} \mathrm{P} \mathrm{ha-1}$ was applied. The increase in pods bearing branches per plant with highest level of phosphorus might be attributed due to the favorable combination of phosphorous and nitrogen which was essential for various plant processes. Secondly, phosphorous might have played a positive role in pod formation. Similar findings were documented by Ghaffar (1990) who observed an increase in pods bearing branches per plant by increasing the phosphorous levels. The interaction of tillage systems and phosphorous was found highly significant. The highest pods bearing branches per plant was recorded in conventional tillage $+90 \mathrm{~kg} \mathrm{P}^{-1}$ and it differed significantly from all other treatments (Table 3). The lowest bearing branches per plant was recorded in zero tillage + $30 \mathrm{~kg} \mathrm{P} \mathrm{ha}^{-1}$. These results were in accordance with that of Jamshidian and Khajehpour (1999); Khan et al. (2002) who reported the higher pods bearing branches per plant under conventional tillage and high phosphorous level.

Table 2. Effect of different phosphorous levels and tillage systems on the yield and yield parameters of mungbean

\begin{tabular}{|c|c|c|c|c|}
\hline Treatments & $\begin{array}{l}\text { Pods bearing } \\
\text { branches per } \\
\text { plant }\end{array}$ & Seeds per plant & $\begin{array}{l}\text { Straw yield (kg } \\
\left.\mathrm{ha}^{-1}\right)\end{array}$ & $\begin{array}{l}\text { Seed yield (kg ha } \\
\text { 1) }\end{array}$ \\
\hline $\begin{array}{l}T_{1} \\
T_{2} \\
T_{3} \\
\text { LSD (0.05) } \\
P_{1} \\
P_{2} \\
P_{3} \\
\text { LSD }(0.05)\end{array}$ & $\begin{array}{l}4.14 \mathrm{c} \\
4.38 \mathrm{~b} \\
4.8 \mathrm{a} \\
0.09 \\
4.35 \mathrm{c} \\
4.45 \mathrm{~b} \\
4.52 \mathrm{a} \\
0.06\end{array}$ & $\begin{array}{l}63.22 \mathrm{c} \\
71.39 \mathrm{~b} \\
81.81 \mathrm{a} \\
7.69 \\
67.53 \mathrm{c} \\
70.64 \mathrm{~b} \\
78.26 \mathrm{a} \\
2.19 \\
\end{array}$ & $\begin{array}{l}3738.3 \\
38.75 \\
3991 \\
\text { NS } \\
3796.3 \\
3870 \\
3938 \\
\text { NS } \\
\end{array}$ & $\begin{array}{l}893.3 \mathrm{c} \\
1008 \mathrm{~b} \\
1142.3 \mathrm{a} \\
32.51 \\
975.3 \mathrm{~b} \\
1004.3 \mathrm{~b} \\
1064 \mathrm{a} \\
35.28\end{array}$ \\
\hline
\end{tabular}

$\mathrm{T}_{1}$ : zero tillage, $\mathrm{T}_{2}$ : minimum tillage, $\mathrm{T}_{3}$ : conventional tillage; $\mathrm{P}_{1}: 30 \mathrm{~kg} \mathrm{ha}^{-1}, \mathrm{P}_{2}: 60 \mathrm{~kg} \mathrm{ha}^{-1}$ and $\mathrm{P}_{3}: 90 \mathrm{~kg} \mathrm{ha}^{-1}$ 
Table 3. Interactive effect of different phosphorous levels and tillage systems on the yield parameters and yield of mungbean

\begin{tabular}{|c|c|c|c|c|}
\hline Treatments & $\begin{array}{l}\text { Pods bearing } \\
\text { branches per } \\
\text { plant }\end{array}$ & Seeds per plant & $\begin{array}{l}\text { Straw yield (kg } \\
\left.\mathrm{ha}^{-1}\right)\end{array}$ & $\begin{array}{l}\text { Seed yield (kg ha } \\
{ }^{1} \text { ) }\end{array}$ \\
\hline$T_{1} P_{1}$ & $4.01 \mathrm{f}$ & $58.13 \mathrm{e}$ & 3642 b & $851 \mathrm{e}$ \\
\hline$T_{1} P_{2}$ & $4.18 \mathrm{e}$ & $64.29 \mathrm{~d}$ & $3744 a b$ & $902 \mathrm{de}$ \\
\hline$T_{1} P_{3}$ & $4.23 \mathrm{de}$ & $67.24 \mathrm{~cd}$ & $3829 a b$ & $927 \mathrm{~d}$ \\
\hline$T_{2} P_{1}$ & $4.32 \mathrm{~cd}$ & $69.51 \mathrm{bcd}$ & $3849 a b$ & $989 \mathrm{c}$ \\
\hline $\mathrm{T}_{2} \mathrm{P}_{2}$ & $4.39 \mathrm{c}$ & $71.84 \mathrm{bcd}$ & $3881 \mathrm{ab}$ & $1013 \mathrm{c}$ \\
\hline$T_{2} P_{3}$ & $4.42 \mathrm{c}$ & 72.83 bc & $3895 a b$ & $1022 \mathrm{c}$ \\
\hline$T_{3} P_{1}$ & $4.73 \mathrm{~b}$ & $74.94 \mathrm{bc}$ & $3898 a b$ & $1086 \mathrm{~b}$ \\
\hline$T_{3} P_{2}$ & $4.78 \mathrm{~b}$ & 75.79 b & $3985 a b$ & $1098 \mathrm{~b}$ \\
\hline$T_{3} P_{3}$ & $4.9 \mathrm{a}$ & $94.71 \mathrm{a}$ & $4090 \mathrm{a}$ & $1243 a$ \\
\hline LSD (0.05) & 0.13 & 8.26 & 422.18 & 59.2 \\
\hline
\end{tabular}

$\mathrm{T}_{1}$ : zero tillage, $\mathrm{T}_{2}$ : minimum tillage, $\mathrm{T}_{3}$ : conventional tillage; $\mathrm{P}_{1}: 30 \mathrm{~kg} \mathrm{ha}^{-1}, \mathrm{P}_{2}: 60 \mathrm{~kg} \mathrm{ha}^{-1}$ and $\mathrm{P}_{3}: 90 \mathrm{~kg} \mathrm{ha}^{-1}$

\section{Seeds per plant}

Results referring to the seeds per plant show that maximum seeds per plant were obtained in conventional tillage and it differed significantly from all other treatments of tillage systems (Table 2). The minimum seeds per plant (63.22) were obtained in zero tillage. These results were supported by the findings of Zamir (2006) who noticed high seeds per plant in conventional tillage. However, it was further disclosed from results that the seeds per plant was significantly affected by different levels of phosphorous. The maximum seeds per plant were produced by the application of $90 \mathrm{~kg} \mathrm{P} \mathrm{ha}{ }^{-1}$ and it differed significantly from all other treatments of phosphorous (Table 2). The minimum seeds per plant were produced by $30 \mathrm{~kg} \mathrm{P} \mathrm{ha}^{-1}$. The uptake of phosphorous increase the uptake of nitrogen which might have positively affected the seeds per plant. Similarly, Dubey et al. (1993) reported significant effect of phosphorous on seeds per plant. The interactive effect of tillage systems and phosphorous levels on the seeds per plant shows that the maximum seeds per plant were produced in conventional tillage $+90 \mathrm{~kg} \mathrm{P}^{-1}$ and it differed significantly from all other treatments (Table 3). The minimum seeds per plant were obtained in zero tillage $+30 \mathrm{~kg} \mathrm{P}$ $\mathrm{ha}^{-1}$ which differed significantly from all other treatments. These results were in accordance with that of Siag and Prakash (2007); Rahman et al. (2008) who also noticed maximum increase in seeds per plant by phosphorus application and conventional tillage.

\section{Straw yield $\left(\mathrm{kg} \mathrm{ha}^{-1}\right)$}

Maximum straw yield was obtained by the conventional tillage which differed non-significantly from other tillage systems. Phosphorous levels especially $90 \mathrm{~kg} \mathrm{ha}^{-1}$ has great impact in the increase of straw yield but it did not differ significantly from others levels (Table 2). The data showed that there was significant interaction between tillage systems and phosphorous levels for straw yield (Table 3). The maximum straw yield was obtained in conventional tillage $+90 \mathrm{~kg} \mathrm{Pha}^{-1}$ which was found at with other treatments. The minimum straw yield was obtained with zero tillage $+30 \mathrm{~kg} \mathrm{Pha}^{-1}$. These results were in accordance with those of Mukundam et al. (2009) who found that the use of phosphorous fertilizer in combination with conventional tillage increased the straw yield of mungbean.

\section{Seed yield $\left(\mathrm{kg} \mathrm{ha}^{-1}\right)$}

The maximum seed yield was obtained by the conventional tillage which varied significantly from other treatments of tillage systems (Table 2). While minimum seed yield was obtained in the zero tillage. These results were supported by the findings of Siag and Prakash (2007), Thiagalingam et al. (1996) and Vyn et al. (1998) who noted that tillage have significant effect on the seed yield of mungbean. The results further disclosed that by increasing phosphorous levels, the seed yield was increased significantly (Table 2). However, the maximum seed yield was obtained by the application of $90 \mathrm{~kg} \mathrm{P} \mathrm{ha}^{-1}$. Whereas the minimum seed yield was obtained by the application of $30 \mathrm{~kg} \mathrm{P}^{-1}$ and it was statistically at par with that of $60 \mathrm{~kg} \mathrm{P} \mathrm{ha}^{-1}$. These results are confirmatory with the findings of Khan et al. (2003). The results showed that there was significant interaction between tillage systems and phosphorous for seed yield (Table 3). The maximum seed yield $\left(1243 \mathrm{~kg} \mathrm{ha}^{-1}\right)$ was obtained in conventional tillage $+90 \mathrm{~kg} \mathrm{P}^{-1}$ which differed significantly from all other treatments. The minimum seed yield was obtained by using zero tillage $+30 \mathrm{~kg} \mathrm{P}^{-1}$ which was statistically at par with zero tillage $+60 \mathrm{~kg} \mathrm{P} \mathrm{ha}^{-1}$. These results were in accordance with those of 
Shafiq et al. (1994) and Jamshidian and Khajehpour (1999) who reported significant effect of tillage and phosphorous on the seed yield of mungbean.

\section{Economic analysis}

Results of economic analysis revealed that maximum total expenditure (377 USD ha ${ }^{-1}$ ) was attained with the conventional tillage $+90 \mathrm{~kg} \mathrm{Pha}^{-1}$ as compared to others. On the other hand, maximum gross (1945 USD ha $\left.{ }^{-1}\right)$ and net income (1568 USD ha-1 $)$ were obtained by employing the conventional tillage $+90 \mathrm{~kg} \mathrm{P}^{-1}$ while minimum gross income (979 USD ha ${ }^{-1}$ )and net income (687 USD ha ${ }^{-1}$ ) were obtained where zero tillage $+30 \mathrm{~kg} \mathrm{P} \mathrm{ha}^{-1}$ was used (Table 4). However, in the case of benefit cost ratio, the maximum value of benefit cost ratio (5.16) was obtained in conventional tillage $+90 \mathrm{~kg} \mathrm{P} \mathrm{ha}^{-1}$. However, the minimum benefit cost ratio (3.36) was attained in zero tillage +30 $\mathrm{kg} \mathrm{P} \mathrm{ha}^{-1}$ (Table 4).

Table 4. Effect of different phosphorous levels and tillage systems on the economics of mungbean production

\begin{tabular}{|c|c|c|c|c|}
\hline Treatments & $\begin{array}{l}\text { Total Expenditure } \\
\left(\text { USD ha }{ }^{-1}\right)\end{array}$ & $\begin{array}{l}\text { Gross income } \\
\left(\text { USD }^{-1}\right)\end{array}$ & $\begin{array}{l}\text { Net income (USD } \\
\mathrm{ha}^{-1} \text { ) }\end{array}$ & Benefit cost ratio \\
\hline$T_{1} P_{1}$ & 291 & 979 & 687 & 3.36 \\
\hline$T_{1} P_{2}$ & 308 & 1120 & 812 & 3.64 \\
\hline $\mathbf{T}_{1} \mathbf{P}_{3}$ & 344 & 1294 & 950 & 3.76 \\
\hline$T_{2} P_{1}$ & 294 & 1115 & 822 & 3.8 \\
\hline $\mathrm{T}_{2} \mathrm{P}_{2}$ & 321 & 1317 & 995 & 4.1 \\
\hline $\mathbf{T}_{2} \mathbf{P}_{3}$ & 352 & 1525 & 1173 & 4.34 \\
\hline$T_{3} P_{1}$ & 305 & 1474 & 1169 & 4.83 \\
\hline $\mathbf{T}_{3} \mathrm{P}_{2}$ & 324 & 1575 & 1251 & 4.86 \\
\hline $\mathbf{T}_{3} \mathbf{P}_{3}$ & 377 & 1945 & 1568 & 5.16 \\
\hline
\end{tabular}

\section{CONCLUSION}

This study inferred that all the applied phosphorous levels and tillage systems produced significant effects on yield and yield related parameters of mungbean. However, phosphorous @ $90 \mathrm{~kg} \mathrm{P} \mathrm{ha}^{-1}$ and conventional tillage could be successfully utilized to increase the yield of mungbean on economic basis in agro-climatic conditions of Faisalabad, Pakistan.

\section{ACKNOWLEDGMENT}

The authors acknowledged the support provided by Analytical Laboratory, University of Agriculture, Faisalabad, Pakistan.

\section{COMPETING INTEREST}

The authors of this manuscript have no competing interests that influence the results and discussion of this paper.

\section{AUTHORS' CONTRIBUTION}

All the authors of this paper played their important role in planning and conducting the experiment. Authors also worked as a team in data recording, arrangement, presentation and paper write up. 


\section{REFERENCES}

Armstrong RD, Millar G., Halpin NV, Reid DJ and Standley (2003). Using zero tillage, fertilizers and legume rotations to maintain productivity and soil fertility in opportunity cropping systems on a shallow Vertosol. Aust. J. Expt. Agri. 43: 141-153.

CIMMYT (1988). From agronomic data to farmer's recommendations. Academic Training Manual CYMMIT. Mexico, D.F., 31-33.

Dubey SK, Sinha AK and Yadva BR (1993). Effect of sodic water and applied phosphorus on the uptake of phosphorus and yield of green gram. J. Ind. Soc. Soil Sci. 4: 208-209.

Ghaffar A (1990). Effect of Phosphorus application on growth and yield potential of mungbean genotypes at constant $\mathrm{N}$ levels. M.Sc. Thesis, Agron. Dept. University of Agriculture, Faisalabad, Pakistan.

GOP (2009). Economic Survey of Pakistan 2008-09. Ministry of Food, Agriculture and Livestock. Federal Bureau of Statistics, Islamabad. 33-35.

Havlin LJ, Beaton JD, Tisdule SL and Nelson WL (2004). Soil fertility and fertilizers: An introduction to nutrient management. $6^{\text {th }}$ Ed. Pearson Education, 156.

Jamshidian R and Khajehpour MR (1999). Effects of seedbed preparation methods on vegetative growth, seed yield and yield components of mungbean. J. Agri. Res. 3: 9-20.

Khan MA, Aslam M, Sultan T and Mahmood IA (2002). Response of phosphorus application on growth and yield of inoculated and uninoculated mungbean (Vigna radiata L.). Int. J. Agri. Bio. 4: 523-52.

Khan MB, Asif M, Hussain N and Aziz M (2003). Impact of different levels of phosphorus on growth and yield of mungbean genotypes. Asian J. Plant Sci. 2: 677-679.

Mukundam B, Ramna M, Venkata, Lakshmi C, Subha and Raja V (2009). Effect of tillage practices and seed priming on growth and yield of upland crops in rice fallows-A review. Agri. Reviews. 30: 253-496.

Nazir S, Bashir E and Bantel R (2004). Crop Production. Grain Legumes. ${ }^{\text {th }}$ Ed. National Book Foundation, Islamabad, Pakistan, 301.

Rahman MN, Bhuiyan MNH, Sutradhar GNC, Rahman MM and Paul AK (2008). Effect of phosphorous and rhizobium inoculation on yield and yield attributes of mungbean. Int. J. Sustain. Crop Prod. 3: 26-33.

Rosner J, Zwarts E, Klik A and Gyuricza C (2008). Conservation tillage systems-soil-nutrient and herbicide loss in lower Austria and the mycotoxin problem, 15 ${ }^{\text {th }}$ International Congress of ISCO 18-23 May 2008, Budapset, Published by the Geographical Research Institute, Hungary, ISBN 9789639545205.

Shafiq M, Hassan A, Ahmad N and Rashid A (1994). Crop yields and nutrient uptake by rainfed wheat and mungbean as affected by tillage, fertilization and weeding. J. Plant Nutr. 17: 561-577.

Shanmugasundaram S (2004). Exploit mungbean with value added products. International Conference on Indigenous Vegetables and Legumes. Prospectus for Fighting Poverty, Hunger and Malnutrition. Acta Hort. 752.

Siag RK and Prakash V (2007). Effect of tillage and fertilizer on the growth and yield of summer mungbean. Acta Hort. 752: 295-297.

Steel RGD, Torrie JH and Dicky DA (1997). Principles and procedures of statistics, a biometrical approach. $3^{\text {rd }}$ Ed. McGraw Hill, Inc. Book Co. New York, 101-108.

Thiagalingam K, Dalgliesh NP, Gould NS, McCown RL, Cogle AL and Chapman AL (1996). Comparison of no-tillage and conventional tillage in the development of sustainable farming systems in the semi-arid tropics. Aust. J. Expt. Agri. 36: 995-1002.

Vyn TJ, Opoku G and Swanton J (1998). Residue management and minimum tillage systems for soybean following wheat. Agron. J. 90: 131-138.

Zamir MS (2006). Agro-economics studies on different rice-based cropping systems at conventional and zero tillage. Ph.D. Thesis. Dept. Agron., Uni. Agri., Faisalabad, Pakistan.

Cite this Article: Muhammad WRM, Zamir MSI and lqbal S, 2014. Impact of Phosphorous Levels and Different Tillage Systems on Yield and Economics of Mungbean (Vigna radiata L.). Greener Journal of Agronomy, Forestry and Horticulture. 2(4):073-078, http://dx.doi.org/10.15580/GJAFH.2014.4.080114315 